University of Nebraska - Lincoln

DigitalCommons@University of Nebraska - Lincoln

\title{
Proso millet (Panicum miliaceum L.) fermentation for fuel ethanol production
}

Devin J. Rose

University of Nebraska-Lincoln, drose3@unl.edu

Dipak Santra

University of Nebraska, Panhandle Research and Extension Center, Scottsbluff, NE, dsantra2@unl.edu

Follow this and additional works at: https://digitalcommons.unl.edu/panhandleresext

Rose, Devin J. and Santra, Dipak, "Proso millet (Panicum miliaceum L.) fermentation for fuel ethanol production" (2013). Panhandle Research and Extension Center. 67.

https://digitalcommons.unl.edu/panhandleresext/67

This Article is brought to you for free and open access by the Agricultural Research Division of IANR at DigitalCommons@University of Nebraska - Lincoln. It has been accepted for inclusion in Panhandle Research and Extension Center by an authorized administrator of DigitalCommons@University of Nebraska - Lincoln. 


\title{
Proso millet (Panicum miliaceum L.) fermentation for fuel ethanol production
}

\author{
Devin J. Rose \\ Department of Food Science \& Technology, University of Nebraska-Lincoln, Lincoln, NE, USA \\ Dipak K. Santra \\ Panhandle Research and Extension Center, University of Nebraska-Lincoln, Scottsbluff, NE, USA \\ Corresponding author -D. J. Rose, 143 Filley Hall, Lincoln, NE 68583, USA; tel 402 472-2802, fax 402 472-1693, email drose3@unl.edu
}

\begin{abstract}
The objective of this research was to determine the conversion efficiency of proso millet to ethanol compared to corn in a bench-scale dry-grind procedure. Seven proso millet cultivars and six advanced breeding lines containing waxy starch were fermented with Saccharomyces cerevisiae and ethanol production was compared with normal corn and "highly fermentable" corn. The highly fermentable corn exhibited the highest fermentation efficiency $(97.0 \pm 1.4 \%)$. Among proso millet lines, those with the highest fermentation efficiencies were: Huntsman $(85.9 \pm 0.6 \%)$, 172-2-9 $(90.8 \pm 0.2 \%), 172-2-13(85.1 \pm 2.5 \%)$, and 182-4-24 $(84.7 \pm 2.1)$. Waxy proso millet lines resulted in higher fermentation efficiencies than the non-waxy proso millet varieties containing normal starch $(82.4 \pm 5.5 \%$ vs. $75.5 \pm 7.4 \%$, respectively, $p=0.01)$. Proso millet distiller's dried grains with solubles (DDGS) contained more protein $(26.6-33.4 \%)$ than the DDGS from corn (17.2-23.4\%). These data indicate that proso millet exhibits promise as a feedstock for ethanol production, especially if breeding programs focus on selecting "highly fermentable" lines for advancement.
\end{abstract}

Keywords: starch, distillers dried grains, corn, Saccharomyces cerevisiae, dry-grind

Abbreviations: DDGS = distillers dried grains with solubles; HFC = highly fermentable corn

\section{Introduction}

Unpredictable temperature and precipitation variations, coupled with frequent, damaging hail make the central High Plains one of the most challenging environments for profitable crop production in the US (Saseendran et al., 2010). Winter wheat is the most economically important dry land crop in this region; however, alternative crops are important for sustainable and profitable farming operations in this region (Burgener et al., 2006).

Proso millet (Panicum miliaceum L.) exhibits desirable characteristics as an alternative crop due to its short growing season and ability to produce grain under limited water on marginal soil with low agronomic inputs (Lyon et al., 2008). Furthermore, inserting proso millet into a winter wheat/fallow rotation improves wheat productivity by preserving deep soil moisture, controlling winter annual grass weeds, and reducing disease and insect pressure (Lyon and Baltensperger, 1995). Winter wheat planted on a no-till field over proso millet stubble is less prone to damage from blowing soil and benefits from increased snow capture compared to wheat planted into summer fallow (Lyon et al., 2008).

The High Plains of the US produces more than $96 \%$ of the national proso millet crop (US Department of Agriculture [USDA], 2007). In 2008, annual production was $3.3 \times 10^{5}$ metric tons at a value of $\$ 52$ million, with $\$ 16$ million in exports to 32 countries (Colorado State Department of Agriculture, 2012). In the US, proso millet is used for bird and livestock feed
(Baltensperger et al., 1995); however demand varies significantly, resulting in extreme price volatility. In the last 5 years, ing additional uses for proso millet $\mathrm{m}$ the market value has fluctuated from a low of $\$ 2.87 /$ bushel in 2009 to a high of $\$ 5.87 /$ bushel in 2011 (USDA, 2012). Find ay expand its market and minimize price volatility. Thus, High Plains wheat producers would likely be more able to incorporate proso millet into their cropping rotations and benefit from its agronomic benefits.

One potential alternative use of proso millet grain is fuel ethanol production (Taylor et al., 2006). Proso millet contains starch contents similar to other grains (Parameswaran and Sadasivam, 1994; Nuss and Tanumihardjo, 2010), and has been shown to be a good substrate for malting and fermentation (Zarnkow et al., 2010). Furthermore, waxy proso millet varieties are now becoming available (Graybosch and Baltensperger, 2009), which may have excellent fermentation yields. As there are no reports on use of proso millet for fuel ethanol production, the purpose of this research was to compare proso millet to corn (Zea mays) for ethanol yield.

\section{Materials and methods}

\subsection{Grain source, preparation, and analysis}

Proso millet was produced at the High Plains Agricultural Lab research farm (near Sidney, NE, USA) of the University of Nebraska-Lincoln during the most recent (2010) growing season following standard production practices (Lyon et al., 2008) 
and therefore was less than one year old. Samples (13 lines) included seven cultivars and six advanced breeding lines. All of the advanced breeding lines contained waxy starch (Graybosch and Baltensperger, 2009).

Corn used in this study was produced in 2007 at an agronomy farm owned by the University of Nebraska-Lincoln, located near Mead, NE, USA and stored at $-20^{\circ} \mathrm{C}$ until use. One control, designated "check", was a composite of two commodity corn samples (N70-F1 and DK 63-46). The other control, designated "highly fermentable", was a composite of two hybrids (N69-P9 and DK 61-73) that were classified as highly fermentable and recommended for use in the dry-grind fuel ethanol industry by the seed suppliers (Monsanto, Omaha, NE, USA; Syngenta, Omaha, NE, USA).

Grain was milled on a micro-hammer mill (GlenMills, Clifton, NJ, USA) to pass through a $2 \mathrm{~mm}$ screen and analyzed for moisture (method 44-15.02, AACC International, 2012) and total starch (K-TSTA, Megazyme, Bray, Ireland, method 7613.01, AACC International, 2012).

\subsection{Ethanol fermentation and analysis}

Thirty g (dm) of grain were weighed in duplicate into a $250 \mathrm{ml}$ Erlenmeyer flask and $100 \mathrm{ml}$ of $0.1 \% \mathrm{KH}_{2} \mathrm{PO}_{4}$ containing $83.7 \mu \mathrm{l}$ of Spezyme XTRA (1155 U a-amylase activity, Genencor, Cedar Rapids, IA, USA) were added. Spezyme XRTA is a thermostable $\mathrm{\alpha}$-amylase with a $\mathrm{pH}$ optimum between 5.0 and 6.7 (Maršálková et al., 2010). The initial pH of the grain slurries was about 6.5. The flasks were covered with foil and cooked at $95-100{ }^{\circ} \mathrm{C}$ for $60 \mathrm{~min}$. The flasks were vigorously swirled during the first $5 \mathrm{~min}$ and after 30 and $60 \mathrm{~min}$ of cooking. The flasks were then cooled and adjusted to $\mathrm{pH} 4.2( \pm 0.1)$ with $1 \mathrm{M}$ $\mathrm{HCl}$ (about $30 \mathrm{ml}$ ). Then, $25 \mathrm{\mu l}$ of G-Zyme (12 U amyloglucosidase activity, Genencor) were added followed by $1 \mathrm{ml}$ of yeast (Red Star, Milwaukee, WI, USA) suspension prepared as described containing about $10^{9}$ cells/ml (Wu et al., 2008). The flasks were then sealed with rubber stoppers affixed with an S-lock filled with water to allow for $\mathrm{CO}_{2}$ escape and then fermented at $30^{\circ} \mathrm{C}$ for $72 \mathrm{~h}$ (Wu et al., 2008).

Following fermentation, $1 \mathrm{ml}$ of slurry was transferred to a clean tube and frozen $\left(-20{ }^{\circ} \mathrm{C},<2\right.$ weeks) for ethanol analysis, which was performed using a kit (K-ETOH, Megazyme). Fermentation efficiency was calculated based on a theoretical yield of $0.567 \mathrm{~g}$ of ethanol/g starch (Wu et al., 2006). The remainder of the slurry was dried at $60^{\circ} \mathrm{C}$ until a constant weight (48-72 h) and then ground in a coffee mill (Tekmar, Cincinatti, OH, USA) and passed through a $0.853 \mathrm{~mm}$ (US No. 20) sieve to obtain distiller's dried grains with solubles (DDGS).

DDGS were analyzed for proximate composition (methods 08-01.01, 30-25.01, 44-15.02, and 46-30.01, AACC International, 2012) and starch (K-TSTA, Megazyme, method 76-13.01, AACC International, 2012). Conversion factor for \% nitrogen to \% protein was 6.25. Starch analysis on DDGS followed the dimethylsulfoxide modification for samples containing resistant starch. Because this method measures total glucose in a material after treatment with amylase and amyloglucosidase, free glucose and dextrins in the DDGS at the end of fermentation were also assayed as starch.

Fermentation progress was also monitored at 0, 12, 24, 48, and $72 \mathrm{~h}$ in two selected samples: highly fermentable corn and proso millet line 172-2-9. These samples were selected due to their high ethanol yield compared with the remainder of the samples. Fermentation was performed not by repeatedly analyzing one flask, but by fermenting separate flasks representing each time point. Thus, all samples were independent of each other. At the end of the designated time, an aliquot was removed for ethanol analysis and the remainder was dried for starch determination as described.

\subsection{Data analysis}

Data were analyzed with a general linear model analysis of variance using SAS software (version 9.2, SAS Institute, Cary, NC, USA). For statistical differences among means, Fisher's least significant difference test was performed with $a=0.05$. To determine statistical differences between highly fermentable corn and proso millet line 172-2-9 at each time point during fermentation, Student's $t$-tests were performed.

\section{Results and discussion}

\subsection{Grain analysis}

Starch contents were comparable between corn and proso millet (Table 1). Proso millet starch content was similar to pearl millet (Wu et al., 2006).

\subsection{Ethanol fermentation}

The ethanol concentration in the final fermented slurry for the control samples was $7.75 \%(\mathrm{w} / \mathrm{w})$ for the check corn and $9.82 \%(\mathrm{v} / \mathrm{v})$ for the highly fermentable corn control (Table 1). Ethanol concentration in fermented proso millet slurries fell between these values. Several proso millet lines, including Horizon, 172-2-9, 172-2-13, and 182-4-24, resulted in final ethanol concentrations that were statistically similar to the highly fermentable corn.

These final ethanol concentrations were lower than those reported previously for other grains (Wu et al., 2006, 2007, 2008; Wang et al., 2008; Zhao et al., 2009). This is probably because the initial solids content of the fermentation slurries was about $23 \%$ due to liquid added during $\mathrm{pH}$ adjustment compared to $30 \%$ in most studies (Table 1). At lower solids contents, others have shown that final ethanol concentration is reduced to about 7-9\% (v/v; Nichols et al., 2005; Wu et al., 2006), which is comparable to our results.

The highly fermentable corn control induced the most efficient ethanol production at $97.0 \%$, or $0.550 \mathrm{~g}$ ethanol $/ \mathrm{g}$ starch (Table 1). Although no proso millet varieties reached these values for efficiency, Huntsman, 172-2-9, 172-2-13, and 182-424 were nearly as efficient, ranging from 84.7 to $90.8 \%$, or 0.481 to $0.515 \mathrm{~g}$ ethanol $/ \mathrm{g}$ starch.

Several of the proso millet lines used in this study contained waxy starch (Table 1; Graybosch and Baltensperger, 2009). On average, these samples resulted in higher ethanol yields and fermentation efficiencies than the proso millet varieties that contained normal starch. Others have shown that grains containing waxy starch show greater ethanol conversion efficiencies (Zhao et al., 2009), although other characteristics such as starch extractability are also important (Bothast and Schlicher, 2005).

Ethanol production using proso millet line 172-2-9 was monitored at several time points during fermentation and compared with the highly fermentable corn control to determine if fermentation time could be reduced without substantial loss in ethanol production (Figure 1). Line 172-2-9 was selected because it resulted in the highest final ethanol yield and fermentation efficiency among the proso millet varieties (Table 1). This line showed statistically lower ethanol production at 12 and $24 \mathrm{~h}$ of fermentation compared with the highly fermentable corn control, but after $48 \mathrm{~h}$ of fermentation, no statistical difference in ethanol production was found. This line had significantly less unfermented starch at $48 \mathrm{~h}$ compared with the highly fermentable corn control; no differences were found at any of the other time points. These data did not suggest that line 172-2-9 would possess a shorter fermentation time than highly fermentable corn. 


\subsection{Distiller's dried grains with solubles analysis}

DDGS yield among proso millet lines were fairly consistent (Table 2). Significantly less DDGS were recovered after fermentation of the highly fermentable corn sample.

Unfermented starch varied widely among control and proso millet samples (Table 2). Except for the check corn sample, these values were similar to previous reports (Nichols et al., 2005; Wu et al., 2006) and similar to residual starch recovered in commercial DDGS from corn (Liu, 2011). Waxy proso millet resulted in significantly less residual starch after fermentation compared with millet containing normal starch, which is consistent with the ethanol data.

Protein was higher in proso millet DDGS compared with corn samples (Table 2). Others have reported lower protein contents in corn (about 7.5-9.5\%; Han and Liu, 2010; Nuss and Tanumihardjo, 2010) compared with proso millet (1115\%; Parameswaran and Sadasivam, 1994; Kalinova and Mourdy, 2006; Bagdi et al., 2011). Ethanol producers rely not only on revenue gained from the sale of ethanol, but also that

Table I. Initial starch and solids content and final ethanol concentration and yield after fermentation of control corn and millet samples (means of repeated experiments).

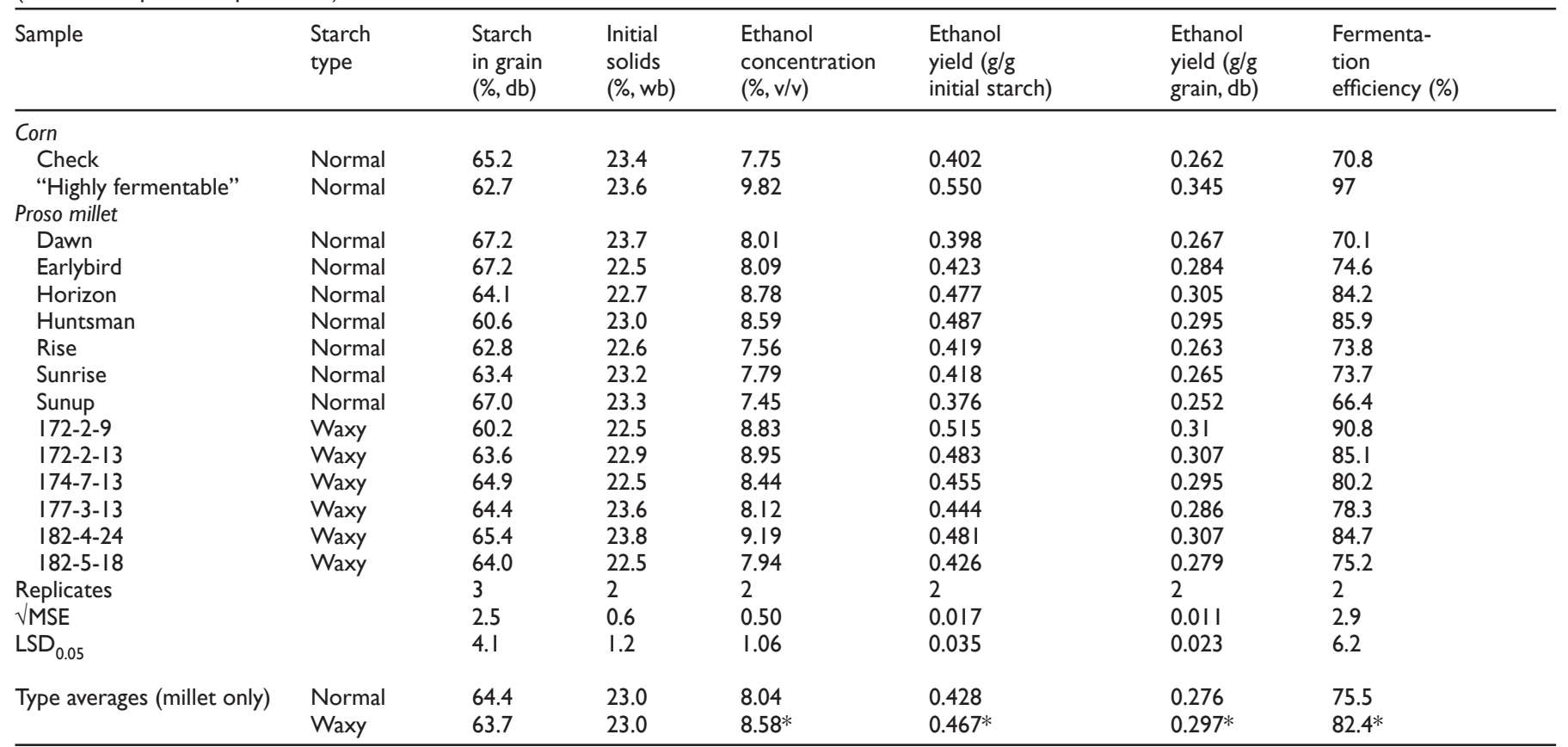

$\mathrm{wb}=$ wet basis; $\mathrm{db}=$ dry basis; $\sqrt{ } \mathrm{MSE}=$ root mean square error; $\mathrm{LSD}_{0.05}=$ Fisher's least significant difference with $\mathrm{a}=0.05$.

*Within the starch type averages, significant difference from normal starch.

Table 2. Distiller's dried grains with solubles (DDGS) yield and composition (means of repeated experiments).

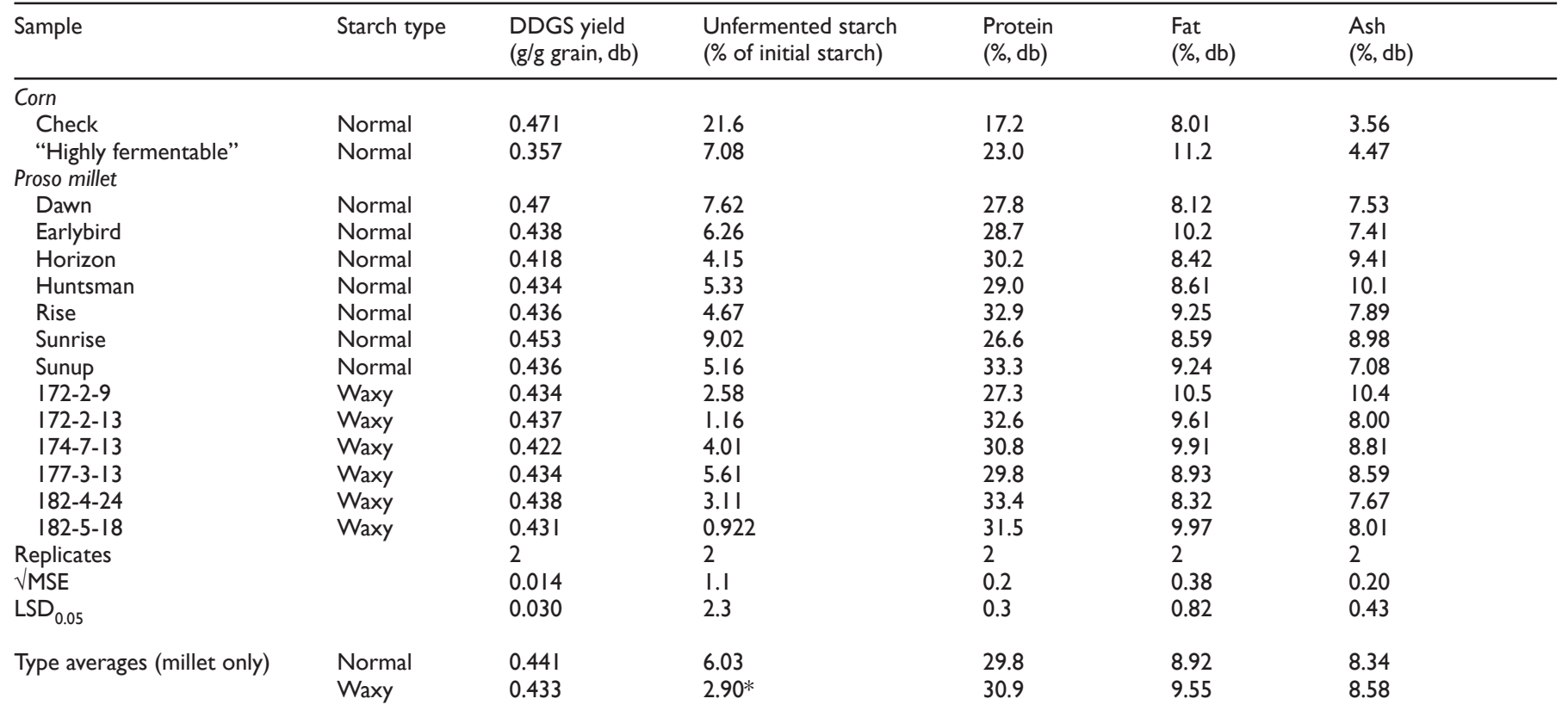

$\mathrm{db}=$ dry basis; $\sqrt{ }$ MSE = root mean square error; $\mathrm{LSD}_{0.05}=$ Fisher's least significant difference with $a=0.05$; unfermented starch refers to total glucose after boiling with dimethylsufloxide and treatment with a-amylase and amyloglucosidase.

*Within the starch type averages, significant difference from normal starch. 


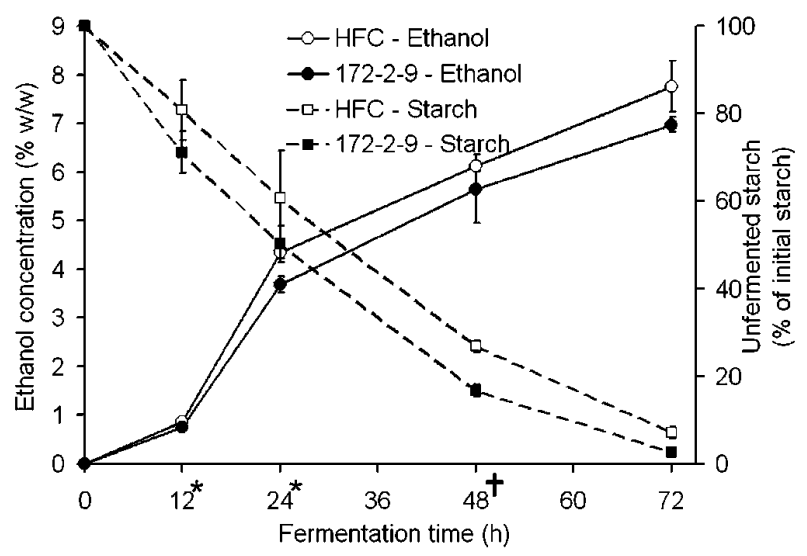

Figure I. Time-course of fermentation of highly fermentable corn (HFC) and proso millet line 172-2-9; $n=2$; error bars show standard deviation (some error bars are too small to plot); $*$ indicates a significant difference $(p<0.05)$ in ethanol production at the time points indicated; $\dagger$ indicates a significant difference in unfermented starch at the time point indicated.

obtained from DDGS. DDGS are valued for their protein content, as this is the most expensive nutrient in animal diets (Belyea et al., 2004).

\section{Conclusions}

Four of the 13 proso millet samples tested in this study resulted in final ethanol concentrations after $72 \mathrm{~h}$ of fermentation that were statistically similar to highly fermentable corn. While fermentation efficiency did not reach that of a highly fermentable corn control, ethanol production was comparable and, in most cases, significantly higher than a check corn. These results indicate that proso millet may be useful in fuel ethanol production. We expect that breeding efforts to select millet varieties with "highly fermentable" characteristics could lead to ethanol production from proso millet that is as efficient as corn. This could provide a new market for proso millet and support farmers in the High Plains of the US.

Acknowledgments - Funding for this research was provided by the Nebraska Wheat Board (award \# 56700018-11).

\section{References}

AACC International, 2012. Approved Methods of Analysis (Methods 08-01.01, 30- 25.01, 44-15.02, 46-30.01, and 76-13.01), eleventh ed. AACC International, St. Paul, MN, USA; online at http://aaccnet. org/ApprovedMethods/default.aspx

Bagdi, A., Balazs, G., Schmidt, J., Szatmari, M., Schoenlechner, R., Berghofer, E., Tomoskozia, S., 2011. Protein characterization and nutrient composition of Hungarian proso millet varieties and the effect of decortication. Acta Aliment. Hung. 40, 128-141.

Baltensperger, D. D., Lyon, D. J., Anderson, R., Holman, T., Stymiest, C., Shanahan, J., Nelson, L. A., DeBoer, K., Heon, G. H., Krall, J., 1995. Producing and Marketing Proso Millet in High Plains (EC95137-C). University of Nebraska-Lincoln Extension, Lincoln, NE.

Belyea, R. L., Rausch, K. D., Tumbleson, M. E., 2004. Composition of corn and distillers dried grains with soluble from dry grind ethanol processing. Bioresour. Technol. 94, 293-298.

Bothast, R. J., Schlicher, M. A., 2005. Biotechnological processes for conversion of corn into ethanol. Appl. Microbiol. Biotechnol. 67, 19-25.

Burgener, P., Baltensperger, D. B., Pavlista, A. P., 2006. Agriculture in Nebraska Panhandle (PHREC 06-15). Panhandle Research and Extension Center, Scottsbluff, NE.
Colorado State Department of Agriculture, 2012. Colorado and US Millet Industry; accessed August 9, 2012, from http://www.colorado.gov/cs/Satellite/Agriculture- Main/CDAG/1251568494181

Graybosch, R. A., Baltensperger, D. D., 2009. Evaluation of the waxy endosperm trait in proso millet (Panicum miliaceum). Plant Breed. $128,70-73$.

Han, J., Liu, K., 2010. Changes in composition and amino acid profile during dry grind ethanol processing from corn and estimation of yeast contribution toward DDGS proteins. J. Agric. Food Chem. 58, 3430-3437.

Kalinova, J., Mourdy, J., 2006. Content and quality of protein in proso millet (Panicum miliaceum L.) varieties. Plant Foods Hum. Nutr. 61, 45-49.

Liu, K., 2011. Chemical composition of distillers grains: a review. J. Agric. Food Chem. 59, 1508-1526.

Lyon, D. J., Burgener, P. A., DeBoer, K. L., Harveson, R. M., Hein, G. L., Hergert, G. W., Holman, T. L., Nelson, L. A., Johnson, J. J., Nleya, T., Krall, J. M., Nielsen, D. C., Vigil, M. F., 2008. Producing and Marketing Proso Millet in the Great Plains (EC137). University of Nebraska-Lincoln Extension, Lincoln, NE.

Lyon, D. J., Baltensperger, D. D., 1995. Cropping systems control winter annual grass weeds in winter wheat. J. Prod. Agric. 8, 535-539.

Maršálková, B., Širmerová, M., Kuřec, M., Brányik, T., Brányiková, I., Melzoch, K., Zachleder, V., 2010. Microalgae chlorella sp. as an alternative source of fermentable sugars. Chem. Eng. Trans. 21, 1279-1284.

Nichols, N. N., Dien, B. S., Wu, Y. V., Cotta, M.A., 2005. Ethanol fermentation of starch from field peas. Cereal Chem. 82, 554-558.

Nuss, E. T., Tanumihardjo, S. A., 2010. Maize: A paramount staple crop in the context of global nutrition. Comp. Rev. Food Sci. F. 9, 417-436.

Parameswaran, K. P., Sadasivam, S., 1994. Changes in the carbohydrates and nitrogenous components during germination of proso millet, Panicum miliaecum. Plant Foods Hum. Nutr. 45, 97-102.

Saseendran, S. A., Nielsen, D. C., Ma, L. W., Ahuja, L. R., Vigil, M. F., 2010. Simulating alternative dryland rotational cropping systems in the central Great Plains with RZWQM2. Agron. J. 102, 1521-1534.

Taylor, J.R.N., Schober, T. J., Bean, S. R., 2006. Novel food and nonfood uses for sorghum and millets. J. Cereal Sci. 44, 252-271.

USDA, 2007. Table 26. Field Crops: 2007 and 2002, Accessed August 2, 2012, from http://www.agcensus.usda.gov/Publications/2007/Full_Report/Volume_1, Chapter_2 US State_Level/ st99 2 026 026.pdf

USDA, 2012. Quick Stats; accessed August 2, 2012, from http://quickstats.nass.usda.gov/

Wang, D., Bean, S., McLaren, J., Seib, P., Madl, R., Tuinstra, M., Shi, Y., Lenz, M., Zhao, R., 2008. Grain sorghum is a viable feedstock for ethanol production. J. Ind. Microbiol. Biotechnol. 35, 313-320.

Wu, X., Wang, D., Bean, S. R., Wilson, J. P., 2006. Ethanol production from pearl millet using Saccharomyces cerevisiae. Cereal Chem. 83, 127-131.

Wu, X., Zhao, R., Bean, S. R., Seib, P. A., McLaren, J.S., Madl, R. L., Tuinstra, M., Lenz, M. C., Wang, D., 2007. Factors impacting ethanol production from grain sorghum in the dry-grind process. Cereal Chem. 84, 130-136.

Wu, X., Zhao, R., Liu, L., Bean, S., Seib, P. A., McLaren, J., Madl, R. Tuinstra, M., Lenz, M., Wang, D., 2008. Effects of growing location and irrigation on attributes and ethanol yields of selected grain sorghums. Cereal Chem. 85, 495-501.

Zarnkow, M., Back, W., Gastl, M., Arendt, E. K., 2010. Impact of proso millet (Panicum miliaceum L.) varieties on malting quality. J. Am. Soc. Brew. Chem. 68, 152-159.

Zhao, R., Wu, X., Seabourn, B. W., Bean, S. R., Guan, L., Shi, Y. C., Wilson, J. D., Madl, R., Wang, D., 2009. Comparison of waxy vs. nonwaxy wheats in fuel ethanol fermentation. Cereal Chem. 86, 145-156. 